\title{
Editorial
}

\section{Narrative History of the Resistance Screening Center: It's Origins, Leadership and Partial List of Public Benefits and Scientific Contributions}

\author{
Ellis Cowling ${ }^{1, *}$ and Carol Young ${ }^{2}$
}

1 Departments of Plant Pathology and Forestry and Environmental Resources, North Carolina State University, Raleigh, NC 27695, USA

2 Resistance Screening Center, Forest Health Protection, Southern Region, USDA Forest Service, Asheville, NC 28806, USA; E-Mail: chy48@charter.net

* Author to whom correspondence should be addressed; E-Mail: ellis_cowling@ncsu.edu; Tel.: +1-919-787-5733; Fax: 919-787-5733.

Received: 13 June 2013; in revised form: 24 June 2013 / Accepted: 2 August 2013 /

Published: 22 August 2013

\begin{abstract}
Forty years ago, the US Department of Agriculture (USDA) Forest Service developed and currently operates the Resistance Screening Center near Asheville, North Carolina, as a service to both industry and university-based tree improvement programs and tree-seed exporting companies in the southern US, Mexico, and Central America. Seed lots from more than 15,000 selections of slash and loblolly pines have been evaluated for genetically-controlled resistance to fusiform rust and other diseases including pitch canker, dogwood anthracnose, and brown spot needle blight. The screening system uses a greenhouse-based artificial inoculation system with controlled density of inoculum from geographically diverse sources of the rust pathogen. Results are completed in 6-9 months and are reasonably well-correlated with field-based progeny tests. Operating costs of the Center are shared by both the USDA Forest Service and its clients. The technologically sophisticated methods and professional skills of the Center staff have been applied to facilitate and accelerate progress in region-wide timber production, scientific understanding of the fusiform rust pathosystem, and graduate education of forest geneticists and pathologists in universities.
\end{abstract}

Keywords: tree improvement; disease resistance; fusiform rust; pitch canker; screening center 


\section{Introduction}

\section{Proposal for Creation of a Southern Pine Rust Resistance Testing Center}

This proposal is not a finished document. Inspiration for this proposal was provided by a lecture presented by Dr. Norman Borlaug at a NATO Advanced Study Institute on the Basic Biology of Rust Resistance in Forest Trees in Moscow, Idaho during the summer of 1969. The idea evolved further during discussions in the spring of 1970 with Roger Blair, Robert Callaham, Ronald Dinus, David Dwinell, Larry Grand, Robert Hare, George Hepting, Thomas Miller, Harry Powers, James Rowan, Dan Schmidt, Glenn Snow, Kim von Weissenberg and Bruce Zobel.

It is intended mainly as a basis for discussion (and hopefully some action) at an informal workshop on genetic resistance to fusiform rust at Bainbridge, Georgia in May 1970. Comments and criticisms concerning both the idea of such a center, its functions, and implementation are solicited from all who share a concern with the health of pines and the welfare of people whose livelihood depends on the productivity of these trees in the southern United States.
Raleigh, North Carolina
R. A. Lewis
May 1, 1970
E. B. Cowling

During the past 20 years, fusiform rust (caused by Cronartium fusiforme Hedge. and Hunt ex Cumm.) has become progressively more destructive of loblolly and slash pines in the southern United States. This increase has been attributed to: (1) widespread planting of infected nursery stock [1]; (2) establishment of susceptible species of pines over large areas of land that frequently include sites to which these species were not well adapted [2]; (3) increased populations of the alternate (oak) host of the pathogen due to suppression of wild fire; and (4) intensive management practices such as site preparation [3]; and fertilization of forest lands [4].

Current losses in growth of useable timber caused by fusiform rust total about 280,000,000 board feet each year [5]. At 1970 market prices this amount of timber is worth about $\$ 10,000,000$ on the stump and about $\$ 250,000,000$ as finished pulp and wood products. Thus fusiform rust is a disease of significant economic importance to the forest economy of the South.

Application of fungicides has provided a satisfactory and economical method of control of the disease in forest nurseries; this has substantially reduced losses attributable to planting of infected nursery stock. But silvicultural or chemical means of control in forest stands are both ineffective and economically impractical on a large scale. Chemical control also involves the hazard of undesirable side effects on the forest environment. Thus, genetically controlled resistance to fusiform rust offers the most promising method of control for the disease in future plantations of loblolly and slash pines. Plantations of these two species now cover about 15,000,000 acres in the South. This area is increasing at about 1,000,000 acres per year.

Genetically controlled variation in resistance to fusiform rust is known to exist both among and within various species of pines in the South [6-11]. Shortleaf and longleaf pines are highly resistant to the disease as are hybrids of shortleaf $\times$ slash and shortleaf $\times$ loblolly pines. Genetically controlled 
resistance has also been discovered among selections of both loblolly pine [10-12] and slash pines $[8,13,14]$.

Substantial need exists among industrial and individual forest landowners as well as state and federal managers to obtain and use rust-resistant planting stock. This need is particularly important in certain areas of South Carolina, Georgia, Alabama, and Mississippi where fusiform rust frequently precludes successful economic management of loblolly and slash pines in plantations. To satisfy this need, seed of genetically resistant loblolly and slash pines must be produced and seedlings made available for development of plantations. Ideally this seed should be obtained from sources of high and consistent resistance to the disease. In some of the areas listed above, trees of low and inconsistent resistance would probably give more satisfactory yields of timber than the unselected planting stock presently available from forest nurseries.

Selection of rust-free parent trees and field testing of open or controlled-pollinated progeny of such parents have been the major techniques for selection and evaluation of resistance in loblolly and slash pines. Although progeny testing is essential in all tree-improvement programs, many difficulties are inherent in field tests for disease resistance. These difficulties include: (1) variation in amount of inoculum from year to year; (2) possible variation in the virulence of the pathogen from locality to locality and year to year; (3) variation in microclimate conditions that influence the amount of infection; (4) changes in susceptibility with age; (5) variation in soil factors that may influence susceptibility, etc.

Although knowledge of the influence of these various factors on the amount and development of the disease is increasing, our ability to control and thus to increase the efficiency of field tests is limited. Thus, procedures are needed for artificial inoculation of seedling populations to supplement field tests. Recently, substantial progress has been made in the development of methods for artificial inoculation of pine seedlings. These developments provide a basis for confidence that a center for testing pines for resistance to fusiform rust could accelerate the process of selecting and evaluating plants for resistance to this disease.

\subsection{Purpose of the Proposed Center}

The proposed Center is envisioned primarily as a service organization. Its major function would be to test seedlings for resistance to fusiform rust. These tests would be performed and the results provided to any private, industrial, cooperative, state, federal or other organization engaged in pine seed production, tree improvement, disease resistance, or other forest research and development activities. Tests would be performed in return for fees that would cover at least a portion of the operating expenses of the service organization.

In addition to performing tests for disease resistance, the proposed Center could provide a central facility for development, maintenance, and exchange of: (1) collections of spores of C. fusiforme from various geographical regions throughout the South; and (2) seeds and/or seedlings of outstanding susceptibility and resistance to fusiform rust for use as markers in progeny tests. Later in its development the center might also maintain for exchange among interested agencies: (1) Pollen from resistant parents for use in breeding for disease resistance; (2) seeds and scions from resistant crosses and parent trees for use in establishing seed orchards for production of seed of rust-resistant pines; (3) 
seeds or clonal lines of pines showing unusual mechanisms or degrees of resistance and susceptibility for research on the mechanisms of disease resistance; (4) spores of racial variants of $C$. fusiforme as they are discovered; and (5) sets of oaks and pines that can be used as different [differential] hosts for racial variants of the fungus.

The proposed Center could also provide an additional mechanism for communication among agencies involved in pine-seed production, tree improvement, disease-research, and disease-control activities.

\subsection{Justification}

At present no agency is providing the kinds of services that would be available from the proposed Testing Center. Each existing disease-research and tree-improvement agency performs its own tests for resistance to fusiform rust. Inevitably, these tests vary greatly as to technique and conditions so that it is difficult to relate the results of one study to those of another or those conducted at one time conducted by the same agency at another time. Relative evaluations of various techniques are needed both for the purposes of comparing the results of past investigations and for improvement of existing methods of screening for disease resistance. Standardized methods involving careful control of the sources and density of inoculum and the environmental conditions before, during, and following inoculation could substantially reduce these difficulties of interpretation.

Many investigators have been reluctant to release resistant selections until they are certain of the stability of the resistance they have observed. The desire to combine disease resistance with other important characteristics of trees before release has also delayed the process of providing rust-resistant planting stock to land owners. While continued intensive testing may always be desirable, it is not always practical. For example, almost irrespective of its possible short-comings in terms of straightness of bole or length of fiber, a plantation that contains $50 \%$ stem infections in an area of high disease hazard is more likely to produce a crop at the end of a rotation that sustains $70 \%$ or $90 \%$ stem infections. Also, land owners that must plant this year or next can ill afford to wait for the researcher to produce an optimum growing stock. The proposed Center could greatly accelerate the process of testing for disease resistance. This should decrease the time that elapses before it is possible to release selections of pines with at least some increased probability of satisfactory growth at rotation age.

\subsection{Techniques for Resistance Testing}

Various artificial inoculation techniques have been developed for measuring the resistance of pines to fusiform rust [3,7,15-18]. Most of these methods provide a moist atmosphere around seedlings exposed to basidiospores released from excised telial columns, or oak leaves, or oak branchlets. The percentage of seedlings showing visible galls after several months in a greenhouse or nursery bed is taken as an inverse measure of rust resistance. Most of these methods have one or more of the following limitations: (1) differences in the origin and condition of basidiospores from one test to another; (2) variation in the density of inoculum applied to the seedlings both within and between test runs; (3) incomplete control of temperature and/or relative humidity during or following deposition of basidiospores; and (4) variation in nutritional status of the seedlings prior to and following inoculation. Recent developments have provided means to limit the influence of each of these sources of variation. 
Storage of basidiospores without loss of infectivity has been achieved and can be used to reduce variation due to differences in origin of basidiospores [3]. Control of inoculum density has been achieved recently by at least two separate methods [15,19]. Controlled environment chambers can limit variation in temperature and relative humidity. Uniform growth media could be used and thus substantially reduce variation due to differences in nutritional status.

No specific recommendations about the type of inoculation procedure, sources of inoculum, or design of specific tests for use at the proposed Center are made as a part of this proposal. These decisions should be made by a group of advisors selected to guide the development of the proposed Center and its testing services.

\subsection{Advisory Board for the Proposed Center}

Since the major function of the proposed Center will be to test seedlings for resistance to fusiform rust, the Advisory Board for the Center logically should include representatives of four major groups or agencies: (1) pathologists experienced with artificial inoculation techniques for measuring variation in resistance to fusiform rust; (2) geneticists concerned with breeding loblolly and slash pines for resistance to this disease; (3) industries concerned with development of resistant growing stock; (4) state or federal pest-control personnel concerned with the needs of small land owners for resistant growing stock; and (5) a biometrician. Possible personnel in each category are listed below (Table 1):

Table 1. Personnel for the proposed Southern Pine Rust Resistance Testing Center.

\begin{tabular}{cccc}
\hline Pathologists & Industrialists & Geneticists & Pest Control Personnel \\
\hline David Dwinell & Walt Beers & John Barber & Donald Davis \\
Albert Kais & Warren Carson & Roger Blair & Robert Grady \\
Thomas Miller & Darwin Fender & Ron Dinus & John Graham \\
Harry Powers & Barry Malac & Ray Goddard & Robert Phelps \\
Robert Schmidt & Marvin Zoerb & John Kraus & Peter Laird \\
Glenn Snow & & Dan Schmitt & \\
Fred Matthews & & Bruce Zobel & \\
Biometrician & & & \\
Thomas Dell & & & \\
\hline
\end{tabular}

\subsection{Facilities and Location}

Facilities essential to the functions of the proposed Center would include: 4000-6000 square feet of greenhouse space and associated head-house facilities; four 10 by 10 foot controlled environment chambers; 750 square feet of laboratory space with chemical benches, glassware storage cabinets, refrigerators, microscopes, temperature-controlled incubators, freeze dryer, and other moveable equipment and supplies. These facilities should be located in reasonably close proximity to one of the major forest-disease-research or pest-control centers of the South.

Adequate facilities that meet most of the above requirements will become available at the Bent Creek Experimental Forest near Asheville, North Carolina in July 1971 when the Air-Pollution Project 
of the Southeastern Forest Experiment Station moves to the Research Triangle Park, North Carolina. This location is adjacent to the Zone I Office of the Southeastern Area Division of State and Private Forestry and the Headquarters of the Southeastern Forest Experiment Station.

As presently envisioned, the proposed Center would require the services of one professional and two sub-professional personnel and a half-time secretary. The professional should have training through a master's degree (or equivalent work experience) in both forest pathology and either forest genetics or tree improvement. The sub-professional personnel preferably should have some experience or training in horticulture or nursery work.

\subsection{Financial Support and Institutional Relationships}

The proposed Testing Center is designed to provide a service that will be of value to all types of forest land owners throughout the southern United States. Services would be provided to any and all private, industrial, cooperative, state, federal or other organization engaged in pine seed production, tree improvement, disease resistance, or other forestry research and development activities. Because of these broad, applied, and region-wide responsibilities, it is logical that the U. S. Forest Service should be requested to take the initiative in establishing the proposed Testing Center. It is suggested that the Southeastern Area Division of State and Private Forestry be requested to provide primary administrative and financial support for the Center. The Advisory Board discussed earlier would work closely with the Division in selecting personnel for the Center as well as in designing the facilities, inoculation procedures, fee structures, and the bookkeeping and operational procedures for the Center. The initial costs for development of facilities and continuing support for the professional personnel of the Center probably would need to be provided from this source. Fees for services rendered by the Testing Center probably will be adequate to support the sub-professional and secretarial personnel of the Center.

\section{Initial Steps in Establishing the Proposed Center}

Beginning in 1965, graduate students working with professors Zobel and Cowling at NC State joined together in annual pilgrimages to International Paper Company's Southlands Experiment Forest near Bainbridge, GA. Our goal was to make periodic measurements of growth, form, and rust disease incidence on Dr. Zobel's famous "Heritability Study". On the way, we often stopped by the Athens and Gulfport labs of the US Forest Service to learn more about US Forest Service research on tree diseases and especially the artificial inoculation methods developed at both labs. It was on these trips with graduate students that the idea of a central testing center to screen loblolly and slash pine trees for resistance to fusiform rust really came into focus. Ralph Lewis was the graduate student who volunteered to write the initial proposal presented above.

During 1969, students and faculty at NC State initiated the south-wide "Fusiform Rust Aeciospore Bank". Colleagues in industry, federal, state, and university organizations were requested to join together in collecting aeciospores from individual galls on loblolly and slash pine trees. Squeeze-bulb cyclone collectors and spore collection and storage vials were provided to all cooperators. By December 1971, more than $200 \mathrm{cc}$ of aeciospores had been collected from single galls on dozens of individual trees in 30 counties across the natural range of fusiform rust. These geographically 
referenced collections of spores were then made available for research purposes throughout the region [20].

On May 14, 1970, Ralph Lewis' proposal was presented for discussion at an informal gathering of fusiform rust researchers at International Paper Company's Southlands Experiment Forest. Sometime after this meeting, the proposal was submitted for consideration by leaders in the Washington DC offices of the US Forest Service.

On February 26, 1971, Robert Callaham and David Ketchum announced from their Washington Offices that the Southeastern Area of State and Private Forestry (SA-S\&PF) "has agreed to assume major responsibility for the screening program". They also recommended that SA-S\&PF should "host a meeting as soon as convenient" to work out the "best system" for a "central facility to test seed lots of southern pine for fusiform rust resistance", and to answer additional questions about the location, space, facilities, and longevity of the proposed program.

On May 11, 1971, the recommended meeting was held in the Atlanta office of SA-S\&PF where the following decisions were made: (1) The facility should be located at Asheville, NC - a location which, very importantly, is outside the natural range of the fusiform rust pathogen; (2) Greenhouses and other existing facilities at the Bent Creek Experimental Forest should be used for a "pilot test" of inoculation and evaluation methods; and (3) An advisory committee of experts from universities, forest products industries, and the USDA Forest Service, should be established to guide further development of the Resistance Screening Center (RSC).

On November 23, 1971, after extensive consultation with scientists working with southern tree improvement and fusiform rust resistance, Douglas Craig announced SA-S\&PF's conclusion that the "Concentrated Basidiospore Spray" (CBS) inoculation system developed by the Southeastern Forest Experiment Station (SEFES) offered the most promise for implementation on a large scale". The CBS system was described in detail in a 1971 Office Report titled: "Procedures used in fusiform rust research" [21].

The seven steps of the CBS system are outlined more succinctly in a "Foreword" by Harry Powers in the RSC "Procedures Manual: A Step-by-Step Guide Used in the Operational Screening of Southern Pines for Resistance to Fusiform Rust" for the Resistance Screening Center (RSC) [22,23]. (Figure 1)

On January 4, 1972 the first meeting of the Ad-Hoc Advisory Committee was held at SA-S\&PF headquarters in Atlanta. The committee included seven members: three geneticists - Ray Goddard of the University of Florida, Hans van Buijtenen of the Texas Forest Service, and Bruce Zobel of NC State University; three pathologists - Glenn Snow and Harry Powers of the Southern and Southeastern Forest Experiment Stations and Ellis Cowling of NC State University; and one forester-Tom Swafford from the SA regional office of the Forest Service. Robert Phelps and Peter Laird of SA-S\&PF were asked to serve as non-voting ex-officio members of this Ad-Hoc Advisory Committee. 
Figure 1. Concentrated Basidiospore Spray (CBS) inoculation system used at the Resistance Screening Center. As trays of seedlings in their individual plastic tubes move along a conveyor belt, seedlings are sprayed with the concentrated basidiospore suspension. After inoculation, the trays of seedlings are immediately placed in the controlled temperature and high humidity incubation chamber. After $24 \mathrm{~h}$ in the chamber they are removed to a holding area where they are allowed to equilibrate with normal room conditions for an additional $24 \mathrm{~h}$. Seedlings are then transferred to greenhouses were they remain for 6 months until inspection for fusiform rust symptoms and reports to clients who submitted their seed lots for evaluation for resistance to fusiform rust.

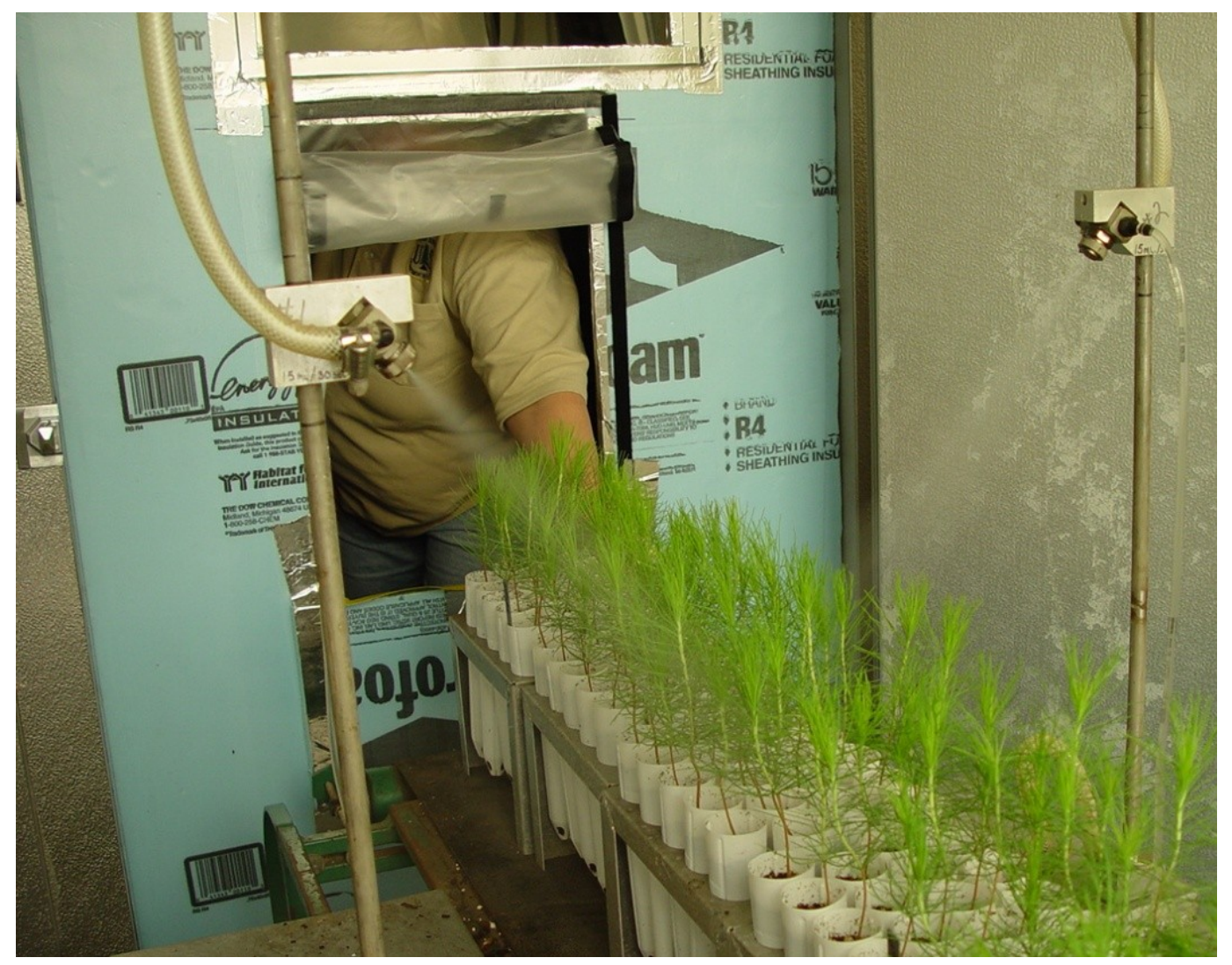

The main purpose of this meeting was review of the plan Peter Laird had developed for the "Pilot Test" of screening center operations beginning in May 1972. The plan was titled "An Evaluation of a Method Designed to Evaluate Fusiform Rust resistance in Slash and Loblolly pines" [24]. Several suggestions for improvement of the plan were made by Committee members.

On June 12, 1972, the second meeting of the Ad-Hoc Advisory Committee was held at the Bent Creek Experimental Forest site where committee members could observe all aspects of the Screening Center's initial operations including progress with the Pilot Test of the CBS system for inoculation of both rust-resistant and rust-susceptible seed lots chosen on the basis of progeny tests for inclusion in the Pilot Test. The Committee was especially pleased with progress Peter Laird and his technicians were making toward automation of the CBS system with fixed-position spray nozzles and a conveyor-belt instead of the hand-held-sprayer and stop-watch method of inoculation used during the Pilot Test. 
The Committee also asked and SA-S\&PF agreed: (1) To further strengthen the Ad Hoc Advisory Committee by adding two more geneticists - Roger Blair of International Paper Company and Ronald Dinus of the Southern Forest Experiment Station, and one more pathologist-Robert Schmidt from the University of Florida; and (2) To transfer responsibility for continuation of the Southwide Fusiform Rust Aeciospore Bank from NC State to the RSC when the Center becomes fully operational (Figure 2).

Figure 2. Fusiform rust aeciospore collection areas (established in 1985) for slash and loblolly pine which are currently maintained by the Resistance Screening Center (RSC).

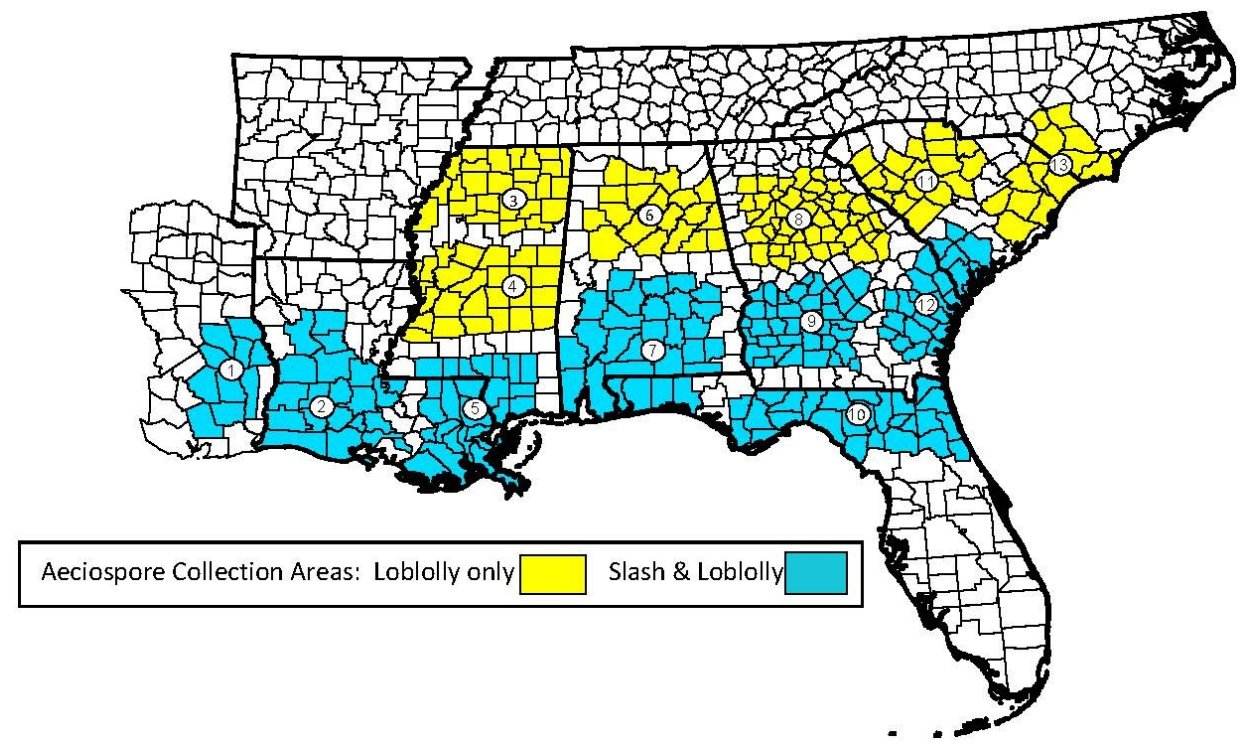

On January 12, 1973, the then enlarged Ad-Hoc Advisory Committee met for the third time-once again at the Screening Center. Here, the seedlings used in the Pilot Test were ready for their 6-month reading of numbers of galls per seed lot. Once again, members of the Advisory Committee were very pleased with progress achieved in the Pilot Test [25]. As a result, the Committee recommended that operational testing of seed lots from individual companies and tree improvement programs should begin as soon as the Pilot Test was completed in September 1973. Thus, beginning in the fall of 1973 the RSC was "open for business" [24-26].

During the remainder of 1973, more than two dozen individual forest products companies and the three university-industry cooperative tree improvement programs in Florida, Texas, and North Carolina submitted a total of 593 seed lots for rust resistance evaluation. During the next few years the total numbers of seed lots submitted were: 733 in 1974, 438 in 1975, and 1011 in 1976. These annual numbers always varied greatly - from a low of 86 in 1979 to a high of 1072 in 1987 and an average of 219 during more recent years-2008-2012. The total number of seed lots submitted for evaluation from 1973-2012 was more than 15,000. Thus the total number of individual seedlings that have been inspected for presence or absence of galls and identification of gall types is about 1.8 million. 


\section{What Organizations Used the Resistance Testing Services of the RSC?}

A large number of southern wood-products and paper companies used and supported the RSC during these 40 years. Most of these companies were members, and also provided both financial and "in-kind” support for the university-industry cooperative tree-improvement programs in Texas, Florida, and North Carolina. Table 2.

Table 2. The 1993 Annual Status Report of the RSC shows the diversity and extent of interest by several different kinds of organizations during 1986 through 1993.

\begin{tabular}{|c|c|c|c|c|c|}
\hline Organization & Seed lots & Organization & Seed lots & Organization & Seed lots \\
\hline Auburn University & 139 & NC State Cooperative & 269 & $\begin{array}{l}\text { University of Florida } \\
\text { Cooperative }\end{array}$ & 808 \\
\hline Champion International & 32 & Nekoosa Packaging Company & 40 & University of Kentucky & 13 \\
\hline Continental Forest Industry & 10 & Owens-Illinois Company & 83 & Union Camp Corporation & 43 \\
\hline Florida Department of Agriculture & 5 & Resistance Screening Center & 702 & USDA Region 8 & 161 \\
\hline USFS Forest Pest Management & 24 & $\begin{array}{l}\text { Southeastern Forest } \\
\text { Experiment Station }\end{array}$ & 65 & Weyerhaeuser Company & 321 \\
\hline Georgia Forestry Commission & 97 & $\begin{array}{l}\text { Southern Forest Experiment } \\
\text { Station }\end{array}$ & 187 & Western Gulf Cooperative & 528 \\
\hline International Forest Seed Company & 195 & Texas A\&M & 10 & University of Tennessee & 92 \\
\hline International Paper Company & 70 & University of Florida & 80 & & \\
\hline
\end{tabular}

\section{What Were the Purposes of the Three Major Types of Screening Tests Conducted by the RSC?}

Beginning in 1973 and continuing through 2012, the various tests conducted at the Screening Center were designed to meet three different kinds of purposes - all three of which contributed in its own way to the quality and value the Center's work in service to individual forest products companies and tree improvement programs in the southern US and the CAMCORE organization in Mexico and Central America.

(1) "Operational" tests were made mainly to identify seed lots with high, medium, and low resistance to fusiform rust. The results of these evaluations then could be used in choosing seed lots to be used as growing stock in plantations in areas of high, medium, and low rust disease hazard and in making decisions about individual selections to be retained in-or rogued from-loblolly and slash pine seed orchards and clone banks.

(2) "Developmental" tests were designed for the purpose of improving the procedures followed in various aspects of Screening Center operations. For example, two studies were performed over a four year period (1979-1983) to evaluate the feasibility of converting to containerized seedlings versus single trays. Several container systems were evaluated with results showing that containerized seedlings would function as well as single trays [27,28] (Figure 3). Converting to containerized seedlings prompted changes in planting media. The switch was made from a mix of 
"mountain top soil", sand and peat moss (which had to be sterilized), to a customized mix of commercial peat moss, vermiculite and perlite. Benefits of using containerized seedlings included: improved efficiency and costs for preparation and use of potting medium; the ability to replace missing or diseased seedlings prior to inoculation; and clients being able to receive their "healthy" uninfected seedlings at the end of testing.

(3) "Research" tests were performed at the request of outside client organizations that wanted to use the technical skills and routine screening tools available at the RSC to test hypotheses at the forefront of forest genetics and pathology. Fortunately, RSC staff had the flexibility necessary to fulfill the requirements of these specialized objectives. Most "Research" tests at the RSC were conducted for one or more of the following four kinds of client-defined scientific purposes: (a) To identify possible histological, physiological, or biochemical mechanisms of resistance to fusiform rust [32]; (b) To determine the number and types of genes that control resistance and susceptibility to fusiform rust in loblolly and pine seedlings [33,34]; (c) To determine the number and types of genes that control virulence and avirulence in the fusiform rust pathogen [35]; and (d) To determine if the gene-for-gene theory of evolution discovered in cereal rust pathosystems also exists in the fusiform rust pathosystem [33] and explore the possibility that additive effects of minor genes may also be involved [36,37].

(4)Other developmental tests performed included more complicated procedural issues such as optimizing the basidiospore inoculum density to maximize discrimination between slash and/or loblolly pine seed lots that should be classified as "susceptible", "moderately resistant" or "highly resistant" to a given geographic source of inoculum, or, alternatively, to a mixed basidiospore inoculum derived from aeciospores collected from several different geographic regions [29-31].

Figure 3. The left panel shows multiple pine seedlings from a specific seed lot that (from 1973-1983) were planted together in trays of locally available mountain topsoil mixed with sand and peat moss. The right panel shows trays of single pine seedlings from a given seed lot that were planted in individual plastic tubes containing a mix of non-sterilized commercially available peat moss, vermiculite, and perlite. These containerized trays of seedlings, each in their individual plastic tubes, were used in all RSC "Operational" and "Research" tests beginning in 1984.
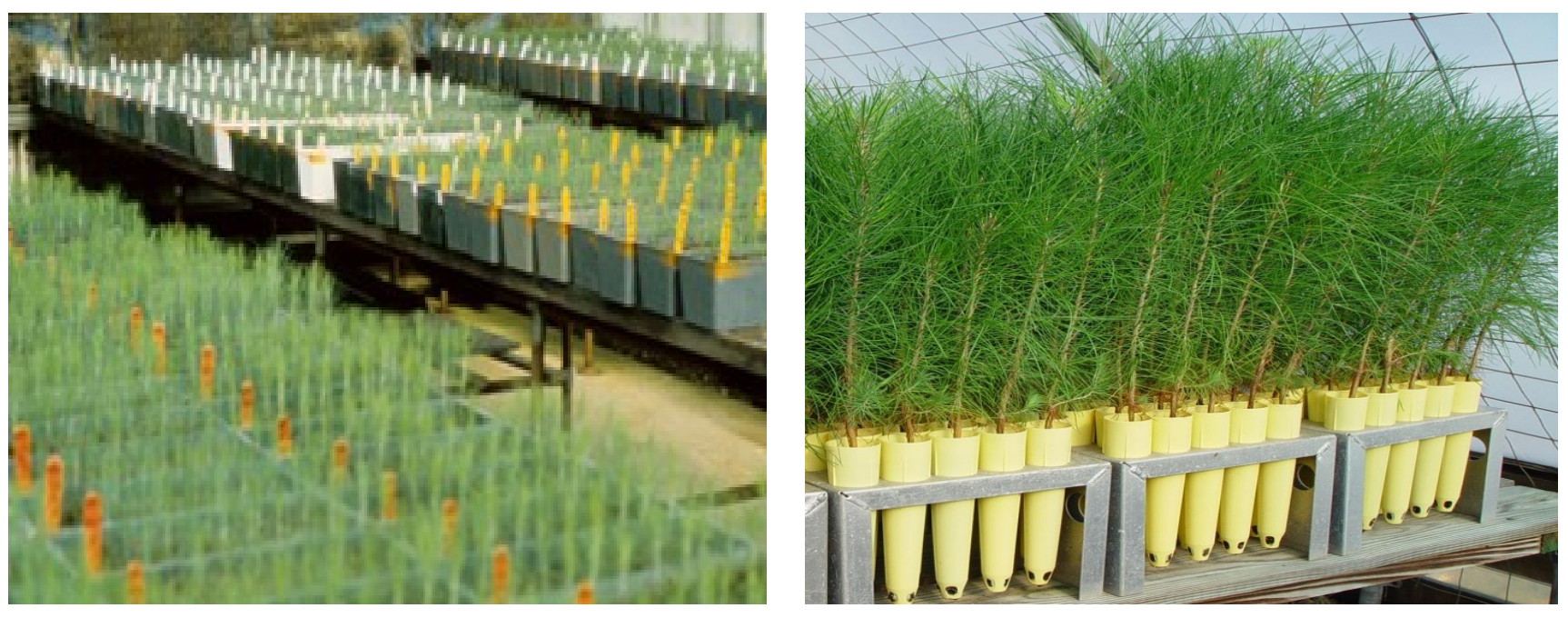


\section{What Steps Were Taken to Increase the Reliability of RSC Results as Predictors of Rust Resistance in the Field?}

Since actual performance in forest plantings is the ultimate goal of all tree improvement programs, there always is serious concern about the reliability of artificial inoculation methods used to predict actual performance in the field. Thus, the questions of "reliability" and "correlation with field test results" were important topics of discussion at RSC Steering Committee meetings from the very beginning.

During the Pilot Test, the fractional number of seedlings in a given seed lot that developed galls of any type was taken as an inverse measure of rust resistance. But since some of these galls had different shapes, sizes, and surface characteristics (which were dubbed short, long, fat, rough, etc.), it was thought that some of these differences in gall characteristics might give some additional evidence of the relative rust resistance of the seedlings in each seed lot.

With these ideas in mind, Sue Hubbard used RSC measurements of these various types and characteristics of galls to develop an initial mathematical "Index of rust resistance" for slash pine seedlings as a part of her PhD dissertation research [38] with Bruce Zobel.

Development of a statistically dependable field-performance-predictive index for loblolly pine seed lots proved to be much more difficult than for slash pine. In pursuit of this objective, Charles Walkinshaw of the Southern Forest Experiment Station at Gulfport moved to Asheville and spent two years seeking to increase the reliability of these mathematical indexes for both loblolly and slash pines [39]. With additional help, often contentious discussion, and repeated trials and comparisons with different sets of seed lots and progeny test results, statistician David Yandle, pathologist Charles Walkinshaw, geneticists Sue Hubbard, Michael Carson, Bob Weir, and technical assistant Alice Hatcher were finally successful in producing statistically reliable field-performance-predictive "indexes of rust resistance" for both loblolly and slash pine seed lots. These index values are now used in reports for all seed lots submitted for "Operational" tests at the RSC [23,31,38-43].

Sue Hubbard was hired by the USDA Forest Service SA-S\&PF to serve as Manager of the RSC from 1978-1982. During these years, Mike Carson and Sue Hubbard completed their PhD degrees, got married, and then departed from their work at the RSC when they both were offered new research appointments in Mike's home country of New Zealand.

\section{What Other Tree Diseases Were Studied at the RSC?}

The early success with artificial inoculations tests for resistance to fusiform rust soon led to consideration of other tree diseases. The disease problems of concern to forest products companies included: pitch canker on longleaf, slash, and loblolly pines; pitch canker on Mexican and Central American pines; dogwood anthracnose; brown spot needle blight; chestnut blight; butternut canker; white pine blister rust; and ozone and other gaseous air pollutants as well as acid rain. Commercial exporters of seed of US forest tree species also turned to the RSC for certification of their seed lots for lack of contamination by disease inducing pathogens especially Fusarium moniliforme var. subglutinans, the incitant of pitch canker. Region 8 of the USDA Forest Service also turned to the RSC for determination of specific gravity of wood in some of their select trees. 
Significant efforts were made at the RSC to develop resistance screening tests for several of these disease problems and wood properties: Pitch canker [44-47]; Dogwood anthracnose [48]; Acid precipitation [49]; or to recommend other organizations to do such tests as was done in the case of air pollutants [50].

Notable successes with other diseases of forest trees were achieved by the RSC-especially with dogwood anthracnose and pitch canker. In this connection, please note the statements provided later in this paper by Mark Windham of the University of Tennessee and William Dvorak of NC State regarding the value of RSC services to the US nursery industry and CAMCORE's international program.

\section{How Did the Major Tree Improvement Programs Use RSC Results in Their On-Going Programs?}

The following statements about on-going uses of RSC results were prepared at our request by leaders of the major university-industry cooperative programs in the southern region. These contributions were prepared by: Tom Byram for the Western Gulf program, Greg Powell for the University of Florida program, Steve McKeand for the NC State program, William Dvorak who leads the Mexican and Central American pines program also at NC State, and Mark Windham for the dogwood anthracnose program at the University of Tennessee. Each statement reflects some unique aspects of their programs' collaborations with the RSC.

The Western Gulf Forest Tree Improvement Program (WGFTIP) submitted seed lots from a total of about 1000 rust-free first-generation slash pine selections for fusiform rust resistance evaluation at the RSC. The top half or approximately 500 parents were found to be moderately or highly resistant to fusiform rust in the Center's artificial inoculation tests. These results were then used to rogue existing seed orchards and to select clones for new orchards with the result that gain in disease resistance observed at the RSC was used in making decisions about selections for inclusion in our program's deployment population.

These data also were used to select parents for crossing in WGFTIP's first-generation field testing program. Early testing for rust resistance at the RSC contributed to the efficiency of the long-term field testing program in two ways: Time and space were not wasted on field testing clearly susceptible parents, and, because crosses made at random among these unproven first-generation parents were more likely to be among rust-resistant parents, the resulting crosses exhibited higher gains in disease resistance. The WGFTIP foresees using the RSC to test future selections that may be poorly challenged in the field due to low levels of rust inoculum.

The WGFTIP currently treats the slash pine planting zones in Texas, Louisiana and South Mississippi as a single deployment zone. Hence, no attempt has yet been made to make site-specific planting recommendations for planting in high hazard areas based on RSC evaluations. Ultimately, however, the patterns of virulence and avirulence discernible only under the artificial inoculation employed by the RSC will be used to better guide deployment decisions, as well as to manage the resistance genes in the breeding population.

The WGFTIP has also used the RSC to screen loblolly pine families deployed in southeast Texas and southwest Louisiana for family-level resistance to pitch canker, an episodic problem in this region. 
All of these families, representing the fastest growing and most commonly deployed families in this region, had significantly less infection than the susceptible control, suggesting that resistance has been captured in the deployment population, but more importantly, captured in the breeding program through selections made from these parents. The incidence of this disease will be monitored to determine if pitch canker resistance should be added as a selection criterion when designing seed orchards or for selecting the breeding population. If the disease becomes an important problem, there appears to be exploitable levels of resistance in the current highly-selected deployment population.

The Cooperative Forest Genetics Research Program (CFGRP) at the University of Florida use results from the RSC mainly to: (1) Screen CFGRP selections for fusiform rust and pitch canker resistance; (2) Help CFGRP graduate students with their research projects; (3) Conduct supportive research in fusiform rust and pitch canker resistance projects; and (4) Screen CFGRP member's slash and loblolly pines to help make choices about deployment population materials.

In 1973 the CFGRP began screening our first-generation slash and loblolly pine selections at the RSC for fusiform rust resistance. Since then, more than 1000 CFGRP selections have been screened. Seed from non-field tested or inadequately field-tested selections were sent to the RSC for fusiform rust resistance screening. At the RSC, selections can be screened in as little as 6 months, using various levels of inoculum that is collected from different deployment zones within the species' natural range.

In 2006 the CFGRP started utilizing the RSC to screen second and third cycle slash pine selections for pitch canker resistance. The purpose of this project is to screen the CFGRP slash pine deployment population for pitch canker resistance and calculate pitch canker resistance rankings. To date 184 selections have been screened and pitch canker resistance ranking have been calculated for those selections. This project is still ongoing.

Two CFGRP graduate students have worked on disease resistances research at the RSC. Patricia Layton ( $\mathrm{PhD}$ 1985) investigated genetic variation in symptomology of slash pine in response to fusiform rust. Also, Sonia Maria De Souza (PhD 1990) studied greenhouse testing of slash pine for resistance to fusiform rust. Her findings indicate that one greenhouse disease resistance test is approximately equivalent to one field test. This student/RSC research relationship has proven to be beneficial to both students and the CFGRP program.

Other CFGRP/RSC research projects have included: (1) initial development of an "index" method for evaluating resistance to fusiform rust beginning in 1987; (2) further validation of the RSC's "index" method beginning in 1990; (3) low inoculum density screening tests for resistance to fusiform rust at the RSC also began in 1990; and (4) screening CFGRP slash pines for resistance to pitch canker beginning in 2006. These projects involved University of Florida faculty, staff, students, some CFGRP Coop member companies, and RSC Staff.

Some CFGRP Coop members routinely send seed from their deployment population to be screened for rust and pitch canker resistance at the RSC where they can specify both the geographic source and the inoculum density to be used. Results of these RSC screenings help members make better-informed seed lot-deployment decisions.

The CFGRP will continue to use the RSC in the future. We have found the RSC to be very cost effective and useful. RSC staff is always very helpful, professional, and knowledgeable.

Initially, the NC State University Cooperative Tree Improvement Program (NCSUCTIP) did not routinely use RSC test results in our breeding programs because of concerns about correlations 
with results from field tests. We still have concerns, but if a given family or select tree is found to be resistant to rust at the RSC, we have confidence that it will also be resistant in the field. If a given seed lot is found to be only moderately resistant or susceptible at the RSC, however, we have not been so confident, because we found some of these seed lots to have significant rust resistance in progeny tests. For that reason, we were concerned that we might be "throwing out some very good trees with some very good genes".

Our most significant uses of results from the RSC have been in the following two areas of investigation:

(1)Our intensively managed "Elite" subsets of mainline populations [51,52]. Since fusiform rust resistance is a very critical trait for most Atlantic Coastal Plain locations, we submitted all seedlings in this Elite subset for special tests at the RSC. We requested that a spore load of 50,000 basidiospores $/ \mathrm{mL}$, rather than the RSC standard of 20,000 basidiospores $/ \mathrm{mL}$, be used from a broad-based mix of aeciospore collections from all Coastal Plain locations. The intent was to challenge the seedlings with an elevated dose of mixed inocula and then cull all seedlings that showed any type of rust gall 6-9 months after inoculation. Our assumption was that seedlings that showed a "no-gall" response at the RSC would be more likely to be resistant in the field than seedlings with galls. In this "Research" test at the RSC, the overall mean infection rate was $48 \%$, ideal for assessing genetic differences. The genetic control for formation of galls was very high, with a half-sib family mean heritability of 0.95 and a full-sib family heritability of 0.93 . Based on these RSC results, and the growth and form data from field trials, we dropped two parents completely and five other crosses from our Atlantic Coastal Plain Elite population. Similar work, results, and decisions also were made with our Piedmont Elite population [52].

(2)From our earlier progeny tests distributed across the South, we identified 25 fast-growing loblolly pine families with a wide range of fusiform rust breeding values. We then submitted seed from these 25 half-sib families for evaluation at the RSC using a mixed inoculum derived from 30 different rust galls at 10 geographical locations across the southern US. From our comparison of results from both field measurements and RSC tests [34], we learned that: (a) all of the families that were susceptible in the field were susceptible in controlled inoculations, and most (12 of 17) of the field-resistant families were resistant in response to controlled inoculations; (b) significant pathogenic variability was observed among the different bulk inocula, although this accounted for only $1.9 \%$ of the total variation; (c) genetic differences among families within field-resistant or field-susceptible groups accounted for $13.7 \%$ of the total variation; and (d) the family by inocula interaction was highly significant, but a single field-resistant family contributed $44 \%$ of the total family by inocula interaction variance, and two other field-resistant families also showed significant interactions.

The NCSUCTIP will continue to submit for rust resistance screening at the RSC, seed from essentially all the select trees in our 4th-cycle breeding program. We also encourage our colleagues at NC State, who are outside of the NCSUCTIP, to utilize the RSC when the Center has expertise with the disease(s) they are researching.

The CAMCORE program is an international tree breeding and conservation program headquartered at NC State but supported by timber industries in Mexico, Central America, and South 
Africa. We have used the RSC to test Mexican and Central American pines for resistance to pitch canker. The original driving force for this effort was the discovery that pitch canker disease had become a major problem on commercial pines in South Africa. Since CAMCORE had access to the RSC, we were able to identify five Mexican pines that showed great tolerance to pitch canker in the seedling stage in the late 1990s. Two of these pine species, P. tecunumanii and P. oocarpa, are now being used commercially as hybrid partners with the commercial species, P. patula, in South Africa. The selected hybrids show no disease symptoms in the field and have greatly improved plantation field survival over the pure commercial species. The success of the RSC in screening for diseases at the seedling level encouraged the South Africans to build their own disease screening center at the Forestry \& Agriculture Biotechnology Institute (FABI) at the University of Pretoria [53-55].

The US Nursery Industry also was greatly benefited by the disease resistance testing services provided by the RSC. These services were critical to the development of "Appalachian Spring", the first cultivar of Cornus florida with resistance to dogwood anthracnose incited by Discula destructiva. It was through meetings sponsored by the RSC that we first learned that a few trees of $C$. florida had survived catastrophic epidemics of dogwood anthracnose in Catoctin Mountain Park, MD in the early 1980's. After searching for survivors for several years and testing their resistance potential in Tennessee, one tree was found to have superior resistance to dogwood anthracnose. With help from Robert Anderson and John Knighten, rooted cuttings were evaluated in a double-blind test at the RSC and the superior resistance of the tree, that became "Appalachian Spring", was confirmed. Without the aid, encouragement, and advice from RSC staff, we would not have been able to release "Appalachian Spring". Today, "Appalachian Spring" is a popular tree in the nursery industry and in 2006 was designated as a "best pick" by Horticulture Magazine [56].

\section{What Are Some of the Major Advances in Scientific Understanding of the Genetics of Fusiform Rust That Have Been Facilitated by Testing Methods Used in the RSC?}

The following six paragraphs were prepared at our request by Henry Amerson and Dana Nelson to describe the work that they and several other colleagues have made in identifying the major genes involved in the fusiform rust pathosystem. As described below, considerable progress has been made but much remains to be investigated.

The leading scientists involved in these studies include: Henry Amerson and Phillip Wilcox of the NC State University Forest Biotechnology Group, George Kuhlman in the Athens, GA Laboratory of the Southeastern Forest Experiment Station, Dana Nelson and Tom Kubisiak in the USDA Forest Service's Southern Institute of Forest Genetics at Saucier, MS. Important contributions also were made by investigators at the Resistance Screening Center, the cooperative tree improvement program at NC State, the University of Florida, and the USDA Forest Service laboratory at Pineville, LA.

The works of Amerson and co-workers, including the initial studies of Wilcox et al. [57] and Nelson et al. [58], have shown that major gene resistance plays an important role in rust resistance in loblolly and slash pines, respectively. To search for major genes in the loblolly pine-fusiform rust pathosystem, a matrix of loblolly pine families and single genotype Cronartium quercuum f.sp. fusiforme ( $C q f$ ) isolates (maintained as urediniospores) was used. Basidiospores derived from the single genotype isolates were inoculated onto seedlings of the families and disease phenotype (gall vs. 
no gall) data and genetic marker mapping were used to discover heterozygous (i.e., segregating) resistance genes in the tree (host) with these genes being called Fr genes. The genetic markers were obtained from megagametophyte DNA for each progeny so the genetic marker status of the maternal parent was being analyzed. In a matrix with progeny (i.e., families) of seven host selections and five pathogen isolates, nine different pathotype specific resistance genes (including $F r 1$ [57] and (Fr1-Fr9, [34,59] have been discovered and tagged with genetic markers. Each selection is heterozygous for resistance ( $\mathrm{Rr}$ ) at one or two of the nine genes and homozygous recessive (rr) for susceptibility, with respect to the remainder of the nine genes. Virulence status for genes in the pathogen that correspond with each Fr gene was also established for each isolate.

In slash pine, Kong [60], working at Texas A\&M University, reported the discovery and genetic marker mapping of a major heterozygous rust resistance gene in a slash pine selection whose progeny were challenged with basidiospores derived from an RSC mixed-gall inoculum. Also, studies by Amerson and co-workers with two other slash pine selections have revealed two heterozygous major resistance genes. For those experiments, progeny of each selection were challenged with basidiospores derived from one of two different single gall collections leading to the discovery of a major resistance gene and accompanying genetic markers in each slash pine selection. However, it is not yet known if the three genes differ from each other, nor do we know if the slash pine genes differ from each of the nine genes identified in loblolly pine.

Based on some of the above described work and additional literature, Nelson et al. [33] concluded that gene-for-gene interactions largely determine fusiform rust gall formation in loblolly and slash pine - that conclusion being firmly supported by the demonstration that host resistance gene Frl and corresponding pathogen avirulence gene Avr1 (discussed below) interact in a gene-for-gene fashion [35]. The RSC and the USDA-FS facility in Athens, GA, both through reliable inoculations and phenotype assessments, have facilitated the investigation of major gene resistance and gene-for-gene interactions.

While nine different Fr genes and genetic markers for these in the loblolly pine selections studied are known, only a single $C q f$ pathogen avirulence gene (i.e., Avr1), has been investigated with genetic marker mapping [35]. That work, with the aid of RSC inoculations and phenotype assessments for pine progeny that segregated at the $F r 1$ locus, used pycnial drop DNA to produce a genetic marker map of a specific single genotype $C q f$ isolate that was heterozygous for virulence against $F r 1$ resistance. Fourteen genetic markers significantly linked to gene $A v r 1$ were found [35]. Further development of genetic marker data in the pathogen to yield allele-specific markers within the actual gene(s) of interest and would not be subject to linkage equilibrium in the overall pathogen population, is yet to occur; but such an advancement would be highly significant because such markers for given Avr genes would allow researchers to examine virulence composition with regards to those genes directly from field collected inoculum [33].

The previously noted approaches have been aimed at discovery of corresponding Fr and Avr genes. But a recently reported study [34,59] examined the interactions of loblolly genes $F r 1-F r 9$ and mixed pathogen (bulked) inocula. This study used open-pollinated progeny (seedlings) of seven loblolly selections (the selections were the maternal parents) which contained nine known heterozygous $\mathrm{Fr}$ genes. These seedlings were challenged at the RSC with basidiospores derived from 10 bulked inocula (each inoculum was a 30-gall mix provided by the RSC from 10 different RSC designated aeciospore 
collection regions across the southeastern US) and assessed for the presence or absence of galls. Genetic markers known from previous work were assessed for each seedling using megagametophyte DNA to identify carriers of known R (resistance) vs. $\mathrm{r}$ (non-resistance) alleles inherited from the maternal parent. This study permitted examination of disease incidence for the seven families, as well as incidence for individuals having the maternally inherited $\mathrm{R}$ and $\mathrm{r}$ genotypes, across and within inocula. With respect to maternal inheritance, $\mathrm{R}$ genotypes typically exhibited less disease than did $\mathrm{r}$ genotypes within each family. Significant differences in virulence against the different $\mathrm{R}$ genotypes were detected in the bulked inocula. Virulence detected for some $\mathrm{R}$ genotypes varied greatly from one inoculum to another [ranging from $0 \%$ disease incidence to $70 \%$ disease incidence for $\mathrm{R} 8$ (the $\mathrm{R}$ allele of Fr8)], while R2 and R5 were moderately to frequently overcome by all inocula. However, for all inocula virulence detected against R3 was low or absent. This variability of virulence against the different $\mathrm{R}$ alleles emphasizes the importance of knowledge regarding the distribution of virulence alleles in the pathogen population.

The following four paragraphs were prepared at our request by Robert Schmidt to describe the work he and other colleagues have been pursuing to describe the strong evidence they have found for so-called "partial resistance" to fusiform rust in addition to the major genes for qualitative resistance in both loblolly and slash pines described in the preceding paragraphs of this article.

The principal investigators involved in this work include Robert Schmidt, Thomas Miller, Carol Young, and K.P. Gramacho. These investigators were especially interested in certain families of slash pine in which a high percentage of the tested seedlings showed "short galls" less than $25 \mathrm{~mm}$ in length 6-9 months after inoculation at the Resistance Screening Center.

Seedlings from these families that showed an abundance of "short galls" were maintained and observed again and again during a 2-3 year period of continuing growth in a greenhouse. During these extended time periods of observation, it became clear that many of the "short galls" did not grow into larger galls, also, many of these "short galls" were often overgrown and virtually disappeared morphologically from the stems of these now sapling-sized trees. Furthermore, if the area where a "short gall" had been observed was still visible, these galls only rarely, if ever, sporulated. And finally, the "abundant short-gall response" was found to be a characteristic response of the pine families being tested and did not vary when different geographic sources of inoculum were used [36].

Subsequent histopathology studies [32] revealed that many of these "short galls" contained a well-developed periderm layer, one or more cells deep, encircling the host reaction zone and the stem circumference and that fungal colonization (hyphae and haustoria) in the stem cortex was severely limited. Such encircling periderm mechanisms of defense have been reported by other investigators.

Since nothing is known regarding the genetic inheritance of these "short gall" traits, these traits should not be referred to collectively as "quantitatively inherited traits" even though the authors believe that these traits very likely are conditioned by quantitatively inherited minor genes.

\section{What Were the Costs and Who Paid the Bills for RSC Operations and Services?}

The total annual cost for operation of the RSC has varied considerably from year to year over the past 4 decades. The original proposal for creation of the Center suggested that these costs would be shared between the forest products companies that would submit seed lots for valuation, and the 
USDA Forest Service's Southeastern Area of State and Private Forestry that had agreed to take "major responsibility to develop and maintain this program" with a steady annual allocation of $\$ 150,000$ "Washington Office" funds.

Beginning in 1973, the client organizations of the RSC were charged \$15 for each seed lot they submitted for "operational" evaluation. This very modest charge was increased to \$53 in 1984 and then to $\$ 100$ per seed lot in 1988 - an amount that remained unchanged since 1988.

An "approximately equivalent" charge also was made for "research" tests designed and requested by an RSC client organization but completed by RSC staff. This charge was based on the total number of seedlings that had to be tested to fulfill the objective of the client's research project divided by 120 - the number of seedlings needed in a typical "operational" test. Thus, after 1987, when the cost per seed lot was $\$ 100$, the client's payment for a research project that required a total of 5000 seedlings to be tested would be 5000 seedlings $/ 120$ seedlings x $\$ 100=\$ 4166$.

The best estimates we have been able to find indicate that the total annual operating costs of the RSC have varied from about $\$ 150,000$ to about $\$ 200,000$ per year. Thus it appears from these estimates of total costs and the numbers of seed lots submitted and the number and size of research projects requested each year, that the USDA Forest Service has provided a very substantial part of the whole cost of the Center's total cost — perhaps as much as $75 \%, 80 \%$, or even $90 \%$ of these costs.

The very modest change in total cost of the RSC (by only about 30 percent over four decades of continuing operations) was made possible by three key factors:

(1) Very substantial increases in efficiency in RSC operations over the years; (2) external sources of support that had a valuable social purpose entirely separate from the mission of the RSC - federally funded programs that provided employment and training for senior citizens (SCSEP) and young adults (YACC). Use of these programs saved the RSC thousands of dollars in salary $(\$ 50,000$ or more) over time. Twenty-five or so senior citizens were utilized by the RSC from the 1970's through the 1990's. The seniors performed many of the more routine functions normally done by much higher paid technicians such as yard and building maintenance, watering plants (for hours at a time), preparing planting media, discarding plants and sterilizing containers for reuse, and janitorial services. Many of these committed men and women remained at the RSC for several years. They enjoyed having a sense of purpose and being able to contribute as well as learning something new. And (3) provision of the facilities (greenhouse/head house, office space, and laboratory space) by the SEFES.

\section{What Graduate Student Research Programs Were Facilitated by the RSC?}

University of Florida: Katherine Smith, MS 2012, PhD anticipated 2014; Tania Quesdad, PhD 2010; Gogce Kayihan, PhD 2006; Scott Luce, MS 2000; Karina Gramacho, PhD 1999; Haiguo Wu, PhD 1996; Michael Popp, PhD 1993; Sonia Maria de Souza, PhD 1990; Patricia Layton, PhD 1985.

NC State University: Hua Li, PhD 2003; Jenny Knoth, MS 2002; Phillip Wilcox, PhD 1995; Jaing Hung, MS 1990; Arn Hu, MS 1989; Karen Papke, MS 1987; Pauline Spaine, PhD 1986; Susan Carson, PhD 1984; Michael Carson, PhD 1983; Dennis Gray, PhD 1982; Tim Adams, MS 1980; Ralph Lewis, PhD 1973; Kim von Weissenberg, PhD 1971; Roger Blair, PhD 1970.

Other Universities for which names of students are not known include University of Kentucky, Auburn University and Stephen F. Austin University. 


\section{Why and How Did the Meetings of the RSC Steering Committee Change over Time?}

From 1972 through most of the 1990's, the periodic (mostly annual) meetings of the RSC Steering Committee were focused primarily on immediate needs and more operational aspects of the screening program itself. Beginning in the late 1990's however, these meetings became occasions for information exchanges among scientists seeking to identify specific genes that control resistance and susceptibility in loblolly and slash pines and both virulence and avirulence in the fusiform rust pathogen itself. Thus, more and more time at these meetings was given to reports of recent scientific advances in the genetics of rust resistance and to the design of future research projects in which the relatively routine methods developed at the RSC could be used to test more advanced hypotheses about the numbers and types of genes involved in the fusiform rust pathosystem.

\section{Who Are the People Whose Creativity, Skills, and Dedicated Service Made the RSC Successful?}

Selection of leading persons and achievements for inclusion in a narrative history of a very collaborative organization is a risky business since some contributions may not be given the credit or priority they deserve. Nevertheless, we venture to mention the following persons and contributions to the success of the RSC and hope that interested readers will help us make this list more complete and accurate.

Ralph Lewis for his initiative in preparing the original proposal for creation of the RSC.

Glenn Snow, Al Kais, Fred Jewell, and Charles Walkinshaw from the Gulfport lab at the Southern Forest Experiment Station for their counsel and advice about screening methods for resistance to brown spot needle blight of longleaf pine and their "infected oak leaves suspended above pine seedlings" method of testing for resistance to fusiform rust.

Tom Miller, Fred Matthews, David Dwinell, and James Rowan for their discovery at the Athens lab of the Southeastern Forest Experiment Station that basidiospores of $C$. fusiforme collected and stored at $\mathrm{pH} 2.0$ and then washed free of acid on Millipore filters retained their capacity to infect and induce galls in pine seedlings; their adaptation of the Coulter electronic particle counter; and their development of the atomized spray technique that became the Concentrated Basidiospore Spray (CBS) inoculation system used routinely at the RSC.

Peter Laird for his design and successful leadership of the RSC's Pilot Test with skillful technical assistance by John Knighten, Robert L. Wolfe, and Tom Gentry.

Charles Walkinshaw, Sue Hubbard, Mike Carson, Bob Weir, and Alice Hatcher who developed the mathematically predictive "Indexes of Resistance" for slash and loblolly pines with skillful statistical counsel and advice by David Yandle.

David Yandle, George Ryan, and Robert Uhler for advice and counsel in developing the RSC's computerized systems for everything from direct reading of symptoms on seedlings, final reports to client organizations, and papers for submission to scientific journals.

Robert Anderson, George Blakeslee and Steve Oak for their leadership in adapting the inoculation and resistance screening methods used for fusiform rust screening for application to other tree disease problems - including pitch canker, brown spot needle blight of longleaf pine, dogwood anthracnose, 
chestnut blight, and white pine blister rust; and also for ensuring that detailed and periodically up-dated Operational Manuals were developed for all of the resistance screening, pathogen detection, and other services provided by the RSC.

John Knighten (1970-1992), Robert L. Wolfe (1970-1978), Carol Young (1973-2007), Joey Triplett (1979-1983), Tom Gentry 1983-1984), Tom McCartney (1985-1989), Cathy Henson (1989-1994), Brenda Susan Minton (1992-present), and Barbara Williams (2005-present) for their years of technical assistance in various aspects of RSC operations.

Peter Laird (1970-1974), Robert D. Wolfe (1974-1976), Sue Hubbard (1977-1982), Robert Anderson (1983-1993), Carol Young (1993-2007), and Josh Bronson (2007-2012) for their leadership and many years of service as on-site "Manager" of the RSC. Ms. Young dedicated her entire 32 year career to the RSC, first as a technician then Manager and takes pride in the RSC's contributions to the forest industry.

Ellis Cowling (1972-1980), Harry Powers (1980-1990), Robert Schmidt (1990-2000), Henry Amerson (2000-2006), Dudley Huber (2006-2012), and Chris Rosier (2012-present) for their effective leadership of the RSC Steering Committees.

Dana Nelson, Robert Weir, Marvin Zoerb, William Lowe, and others whose insightful comments and suggestions at Steering Committee Meetings were so important in the development of the RSC.

Robert Callaham, David Ketchum, Donald Graham, and Keith Shea in the Washington Offices of the US Forest Service for their timely initiative, moral support, and generous financial allocations in support of the RSC.

Robert Phelps, Douglas Craig, Amel Landgraf, Frank Yasinski, Harvey Toko, Dan Brown, Paul Mistretta, and Wes Nettleton in the Atlanta Headquarters of the USDA Forest Service and John Rauschenberger, Jack Thompson, Robert D. Wolfe, Harold Flake, Cindy Huber, Robert Anderson, and William Carothers in the Asheville Field Office of Forest Health Protection for their steadfast administrative and financial support of the RSC.

\section{Conclusions}

Over the past 40 years, the USDA Forest Service has developed and maintained at the Bent Creek Experimental Forest near Asheville, North Carolina a unique regional center for service to tree improvement programs in the southern United States, Mexico, and Central America. This "Resistance Screening Center" has evaluated thousands of seed lots of slash and loblolly pines for resistance to fusiform rust and many hundreds of selections of US, Mexican, and Central American pines for resistance to pitch canker. The RSC has also served commercial tree-seed exporting companies by providing certificates of freedom from contamination by disease-causing pathogens. The Center also has assisted the US nursery industry in developing a commercial variety of flowering dogwood that is highly resistant to dogwood anthracnose.

In addition, especially in recent years, several individual companies and tree improvement programs have developed cooperative agreements with the RSC to use the technical skills and routine screening tools available at the RSC to test hypotheses at the forefront of forest genetics and pathology. These achievements including the identification of nine major genes in loblolly pines and three major genes for resistance to fusiform rust in slash pines that provide genetically controlled resistance to 
corresponding genes for virulence that have been discovered in the fusiform rust pathogen.

Earlier in this article we are pleased to recognize many people who have contributed to the success of the RSC and many graduate students whose dissertation research projects were facilitated by technical skills and testing services provided by the RSC.

In another recent summary paper by leaders of the university-industry tree improvement programs in North Carolina, Florida and Texas, McKeand, Mullin, Byram, and White [61] offer two important consensus judgments: (1) "Deployment of genetically improved loblolly and slash pines ... in the 12 southern states ... dramatically increased productivity; Between 1953 and 1997, the South's timber production more than doubled, its share of US [timber] production increased from $41 \%$ to $58 \%$, and its share of world production increased from $6.3 \%$ to $15.8 \%$ ". (2) "Essentially all of the more than 1.2 billion loblolly pine and 150 million slash pine seedlings planted annually are the result of breeding, testing and selection programs". The RSC has made important contributions to the "testing" and "selection" parts of these breeding, testing, and selection programs.

The importance of the resistance testing services provided by the RSC is mentioned in Robert Schmidt's paper on the biology, ecology, and management of fusiform rust disease of southern pines [62] and is emphasized very clearly in his more recent paper titled "Fusiform Rust of Southern Pines: A Major Success for Forest Disease Management" [63].

The economic value and scientific significance of RSC services to tree improvement programs is also discussed in Dinus and Schmidt's classic "Green Book" treatise on the epidemic of fusiform rust in the southern US [64].

The public service benefits and real financial costs of operations at the RSC were also included as part of a recent economic evaluation of all fusiform rust protection research [65]. Here Cubbage et al. estimated the benefit:cost ratio for all investments in fusiform rust research by federal and state governments, forest products industries, and universities. They believe this ratio to be somewhere between 4:1 and 6:1 — not bad compared to other investments in forestry research in this country and abroad!

In addition, the RSC was instrumental in testing new fungicides for the control of fusiform rust in the nursery industry. For example, in 2007 when the only registered fungicide came under review, the RSC assisted researchers at the Southern Forestry Nursery Management Cooperative (SFNMC), at Auburn University, to find an alternative. Researchers at the university conducted the fungicide applications, and personnel at the RSC conducted the inoculations on treated seedlings. Over the course of 4 years, research tests were conducted and a fungicide registered for control of soybean rust was found to be very useful in controlling not only fusiform rust, but two other diseases that affect pine seedlings (pitch canker and rhizoctonia foliar blight). According to Dr. Scott Enebak (director of the SFNMC) "With Proline ${ }^{\circledR}$, $s$ labeling for use in forest nurseries, growers now have access to one of the most effective tools the industry has ever seen" [66,67].

\section{Acknowledgements}

We are grateful for the statements prepared at our request by Greg Powell, Steve McKeand, Tom Byram, Bill Dvorak, Mark Windham, Robert Schmidt, and both Dana Nelson and Henry Amerson for the sections of this paper on how the major tree improvement programs used RSC 
findings in their on-going tree improvement programs and in making scientific advances in the genetics of fusiform rust. We also appreciate numerous suggestions for improvement of this narrative history of the RSC by Robert Anderson, Joshua Bronson, William Carothers, Fred Matthews, Bro Kinloch, John Knighten, Peter Laird, Thomas Miller, Harry Powers, and Robert L. Wolfe.

\section{Conflicts of Interest}

The authors declare no conflict of interest.

We include here the verbatim text of the original proposal for a rust resistance testing facility for three specific reasons: (1) This document has never before been published and thus has never been available in the open scientific literature of the forest sciences; (2) The senior author, Ralph Lewis was still a graduate student when this proposal was submitted for consideration by senior administrators in the US Forest Service; and (3) So many of document's original recommendations were followed during both the early establishment phase and also during the now 40 year long history of the Resistance Screening Center.

\section{References and Notes}

1. Hodges, C.S., Jr. Diseases in Southeastern Forest Nurseries and Their Control; Research Paper 142; U.S. Department of Agriculture Forest Service, Southeast Forestry Experiment Station: Asheville, NC, USA, 1962; p. 16.

2. Siggers, P.V.; Lindgren, R.M. An old disease-A new problem. South. Lumberm. 1947, 175, $172-175$.

3. Miller, T. Influence of site preparation and spacing on the incidence of fusiform rust in planted slash pines. For. Sci. 1970, 18, 70-75.

4. Boggess, W.R.; Stahelin, R. The incidence of fusiform rust in slash pine plantations receiving cultural treatments. J. For. 1948, 46, 683-685.

5. Powers, H.R. Reductions of disease losses in pine plantations. ALA For. Prod. 1969, 12, 71-75.

6. Jewell, F.F. Disease Resistance Studies in Tree Improvement Research. In Proceeding of the Fifth Southern Conference on Forest Tree Improvement, Raleigh, NC, USA, 11-12 June 1959; pp. 18-20.

7. Jewell, F.F. Infection of artificially inoculated shortleaf pine hybrids with fusiform rust. Plant Dis. Reptr. 1961, 45, 639-640.

8. Barber, J.C. Inherent Variation among Slash Pine Progenies at the Ida Cason Callaway Foundation; Research Paper SE-10; Department of Agriculture Forest Service, Southeast Forestry Experiment Station: Asheville, NC, USA, 1964; p. 90.

9. Jewell, F.F.; Henry, B.W. Breeding for resistance to southern fusiform rust. Proc. Ninth Intern. Congr. 1966, 2, 1694-1695.

10. Kinloch, B.B.; Stonechpher, R.W. Genetic variation in susceptibility to fusiform rust in seedlings from a wild population of loblolly pine. Phytopathology 1969, 59, 1246-1255.

11. Blair, R.L. Quantitative Inheritance of Resistance to Fusiform Rust in Loblolly Pine. Ph.D. Thesis, North Carolina State University, Raleigh, NC, USA, 1970. 
12. Wells, O.O.; Wakeley, P.C. Geographic variation in survival, growth, and fusiform rust infection in planted loblolly pine. For. Sci. Monogr. 1966, 11, 40.

13. Jewell, F.F.; Mallet, S.L. Resistance to fusiform rust in slash pine as shown by artificial inoculation. Phytopathology 1964, 54, 1294.

14. Goddard, R.E.; Arnold, J.T. Screening Select Slash Pines for Resistance to Fusiform Rust by Artificial Inoculation. In Breeding Pest-Resistant Trees; Gerhold, H.D., Schreiner, E.J., McDermott, R.E., Winieski, W.A., Eds.; Pergamon Press: New York, NY, USA, 1966; pp. 431-435.

15. Snow, G.A. Time required for infection of pine by Cronartium. fusiforme and effect of field and laboratory exposure after inoculation. Phytopathology 1968, 15, 1547-1550.

16. Schmidt, R.A. A Literature Review of Inoculation Techniques Used in Studies of Fusiform Rust. In Biology of Rust Resistance in Forest Trees, Proceedings of a NATO-IUFRO Advanced Study Institute, Moscow, ID, USA, 17-24 August 1969; pp. 341-356.

17. Dinus, R.J. Testing slash pine for rust resistance in artificial and natural conditions. In Proceedings of the 10th Southern Forest Tree Improvement Conference, Houston, TX, USA, 17-19 June 1969; pp. 98-106.

18. Dwinell, L.D. An inoculation system for Cronartium. fusiforme. In Biology of Rust Resistance in Forest Trees, Proceedings of a NATO-IUFRO Advanced Study Institute, Moscow, ID, USA, 17-24 August 1969; pp. 327-330.

19. Miller, T. Inoculation of slash pine seedlings with stored basidiospores of Cronartium fusiforme. Phytopathology 1970, 60, 1773-1774.

20. Von Weissenberg, K.; Lewis, R.A.; Cowling, E.B. Fusiform Rust Aeciospore Bank. In Proceedings of the Southwide Forest Disease Conference, Virginia Polytechnic Institute and State University, Blacksburg, VA, USA, 8-10 June 1971; p. 1.

21. Matthews, F.R.; Rowan, S.J.; Dwinell, L.D.; Duncan, H.J. Procedures Used in Fusiform Rust Research; Office Report; Southeastern Forest Experiment Station: Athens, GA, USA, 1971; p. 16.

22. Knighten, J.L.; Young, C.H.; McCartney, T.C.; Anderson, R.A. Resistance Screening Center Procedures Manual: A Step-by-Step Guide Used in the Operational Screening of Southern Pines for Resistance to Fusiform Rust; USDA Forest Service: Asheville, NC, USA, 1988; p. 62.

23. Young, C.H.; Minton, B.S.; Bronson, J.J. Resistance Screening Center Procedures Manual: A Step-by-Step Guide Used in the Operational Screening of Southern Pines for Resistance to Fusiform Rust; USDA Forest Service: Asheville, NC, USA, 2006; p. 52.

24. Laird, P.P.; Knighten, J.L.; Wolfe, R.L. Basic Methodology Used at the Fusiform Rust Testing Facility; Forest Pest Management, Asheville Field Office: Asheville, NC, USA, 1973; p. 14.

25. Laird, P.P.; Knighten, J.L.; Wolfe, R.L. An Evaluation of a Method for Use in Determining Relative Rust Resistance in Loblolly and Slash Pine Families; Forest Tree Resistance Testing Facility Report Number 1; Forest Pest Management, Asheville Field Office: Asheville, NC, USA, 1974; p. 48.

26. Anderson, R.L.; Powers, H.R. The Resistance Screening Center-Screening for Disease Resistance as a Service for Tree Improvement Programs. In Proceedings of the Rusts of Hard Pines Working Party Conference (S2.06-10), Athens, GA, USA, 31 July-6 August 1983; Barrows-Broaddus, J., Powers, H.R., Eds.; pp. 59-65. 
27. Triplett, J.D. Evaluation of a New Seedling Container Design at the Resistance Screening Center; Forest Pest Management, Asheville Field Office: Asheville, NC, USA, 1982; p. 8.

28. Anderson, R.L.; Hubbard, S.D.; Ryan, G.W. Comparison of Two Pine Seedling Container Systems Used at the Resistance Screening Center. In Tree Planter's Notes Summer; USDA: Washington, DC, USA, 1982; pp. 27-30.

29. Laird, P.P.; Knighten, J.L.; Wolfe, R.L. Reduced Inoculum Density Enhances Sensitivity of Resistance Screening Detection in Fusiform Rust Resistance Testing; Report Number 74-1-10; Forest Pest Management, Asheville Field Office: Asheville, NC, USA, 1974; p. 10.

30. Hubbard, S.D. Resistance Screening Center Test 103-80; Report No. 80-1-24; Forest Pest Management, Asheville Field Office: Asheville, NC, USA, 1980; p. 8.

31. Hubbard, S.D.; Triplett, J.D.; Oak, S. Inoculation Systems Comparison at the Resistance Screening Center; Report No. 81-1-39; Forest Pest Management, Asheville Field Office: Asheville, NC, 1981; p. 6.

32. Gramacho, K.P.; Miller, T.; Schmidt, R.A. Comparative histopathology of host reaction types in slash pine resistant to Cronartium. quercum f.sp. fusiforme. Forests 2013, 4, 319-328.

33. Nelson, C.D.; Kubisiak, T.L.; Amerson, H.V. Unraveling and managing fusiform rust disease: A model approach for coevolved forest tree pathosystems. For. Path. 2010, 40, 67-72.

34. Isik, F.; Amerson, H.V.; Whetten, R.S.; Garcia, S.A.; McKeand, S.E. Interactions of Fr genes and mixed-pathogen inocula in the loblolly pine-fusiform rust pathosystem. Tree Genet. Genomes 2012, 8, 15-25.

35. Kubisiak, T.L.; Anderson, C.L.; Amerson, H.V.; Smith, J.A.; Davis, J.M.; Nelson, C.D. A genomic map enriched for markers linked to Avr1 in Cronartium. quercuum f.sp. fusiforme. Fungal Genet. Biol. 2011, 48, 266-274.

36. Schmidt, R.A.; Gramacho, K.P.; Miller, T.; Young, C.H. Components of partial resistance in the slash pine-fusiform rust pathosystem. Phytopathology 2000, 90, 1005-1010.

37. Gramacho, K.P.; Schmidt, R.A.; Miller, T. Stability of slash pine families with major gene and partial resistance to single gall and mixed gall inocula of Cronartium quercum $\mathrm{f}$. sp. fusiforme in greenhouse studies. Forests 2013, 4, 488-499.

38. Hubbard, S.D. An Index for Selection of Relative Rust Resistance Using Tree Seedling Symptom Types. A Proposition for Partial Fulfillment of Degree Requirements for the Ph.D. at North Carolina State University, Raleigh, NC, USA, 1981; p. 25.

39. Walkinshaw, C.H.; Hubbard, S.D.; Triplett, J.; Anderson, R.L. How to Identify Six Different Fusiform Rust Symptom Types on Seedlings at the Resistance Screening Center; Report No. 82-1-5; Forest Pest Management, Asheville Field Office: Asheville, NC, USA, 1981; p. 8.

40. Walkinshaw, C.H.; Dell, T.R.; Hubbard, S.D. Predicting Field Performance of Slash Pine Families from Inoculated Greenhouse Seedlings; Research Paper SO-160; USDA Forest Service: Gulfport, MS, USA, 1980; p. 6.

41. Hatcher, A. A Comparison of Rust Resistance Evaluations: Field Tests vs. Resistance Screening Center Tests; N.C. State University-Industry Cooperative Tree Improvement Cooperative, NC State University: Raleigh, NC, USA, 1992; p. 10. 
42. Hatcher, A. A Comparison of Rust Resistance Evaluations: Field Tests vs. Resistance Screening Center Tests; N.C. State University-Industry Cooperative Tree Improvement Cooperative, NC State University: Raleigh, NC, USA, 1993; p. 30.

43. Hatcher, A. A Comparison of Rust Resistance Evaluations: Field Tests vs. Resistance Screening Center Tests; N.C. State University-Industry Cooperative Tree Improvement Cooperative, NC State University: Raleigh, NC, USA, 1995; p. 27.

44. Anderson, R.L. New method for assessing contamination of slash and loblolly pine seeds by Fusarium moniliforme var. subglutinans. Plant Dis. 1986, 70, 452-453.

45. Anderson, R.L. Pine-Pitch Canker Fungus. Worksheet No. 56, Chapter 7. In ISTA Handbook on Seed Health Testing; International Seed Testing Association: Zurich, Switzerland, 1987; p. 6.

46. Blakeslee, G.; Oak, S.W. Pitch Canker Resistant Slash Pine Identified by Greenhouse Screening at the Resistance Screening Center; Report No. 88-1-44; Forest Pest Management, Field Office: Asheville, NC, USA, 1988; p. 12.

47. Young, C.H.; Minton, B.S.; Bronson, J.J. Resistance Screening Center Procedures Manual: A Guide Used in the Operational Screening of Pines for Resistance to Pitch Canker Disease; USDA Forest Service, Forest Health Protection: Asheville, NC, USA, 2006; p. 21.

48. Anderson, R.L. Development of an Inoculation System for Infection of Flowering Dogwood with Discula sp. at the Resistance Screening Center; Report No. 91-1-34; Forest Pest Management, Asheville Field Office: Asheville, NC, USA, 1991; p. 5.

49. Anderson, R.L.; Barang, P.; Knighten, J.; Lawton, K.A.; Britton, K.O. Pretreating dogwood seedlings with simulated acidic precipitation increases anthracnose symptoms in greenhouse-laboratory trials. Can. J. For. Res. 1993, 23, 55-58.

50. Drummond, D.B. The Feasibility of Screening Southern Pines against Air Pollutants at the Resistance Screening Center; Forest Pest Management, Asheville Field Office: Asheville, NC, USA, 1982; p. 13.

51. North Carolina State University Cooperative Tree Improvement Program (NCSUCTIP). Clonal Testing of Atlantic Coastal Elite (ACE) Population; 52nd Annual Report of the North Carolina State University Cooperative Tree Improvement Program; NC State University: Raleigh, NC, USA, 2008; pp. 1-2.

52. North Carolina State University Cooperative Tree Improvement Program (NCSUCTIP). Third-Cycle Elite Breeding Progress: Atlantic Coastal Elite (ACE) Population and Elite Diallel Population (PEDP); 56th Annual Report of the North Carolina State University Cooperative Tree Improvement Program; NC State University: Raleigh, NC, USA, 2012; pp. 4-5.

53. Nel, A.; Hodge, G.R.; Mongwaketsi, K.E.; Kanzler, A. Variation in pitch canker fungus (Fusarium. circinatum) resistance among open-pollinated families of Pinus. patula tested at screening facilities in the USA and South Africa. South. For. 2013, Submitted.

54. Dvorak, W.S.; Hodge, G.R.; Kietzka, J.E. Genetic variation in survival, growth, and stem form of Pinus. leiophylla in Brazil and South Africa and provenance resistance to pitch canker. South. Hemisph. For. J. 2007, 69, 125-135.

55. Dvorak, W.S.; Potter, K.M.; Hipkins, V.D.; Hodge, G.R. Genetic diversity and gene exchange in Pinus. oocarpa, a Mesoamerican pine with resistance to the pitch canker fungus (Fusarium. circinatum). Int. J. Plant Sci. 2009, 170, 609-626. 
56. Windham, M.T.; Graham, E.T; Witte, E.T.; Knighten, J.L.; Trigiano, R.N. Cornus. florida "Appalachian Spring": A white flowering dogwood resistant to dogwood anthracnose. Hort. Sci. 1998, 33, 1265-1267.

57. Wilcox, P.L.; Amerson, H.V.; Kuhlman, E.G.; Liu, B.H.; O’Malley, D.M.; Sederoff, R.R. Detection of a major gene for resistance to fusiform rust disease in loblolly pine by genomic mapping. Proc. Natl. Acad. Sci. USA 1996, 93, 3859-3864.

58. Nelson, C.D.; Doudrick, R.L.; Nance, W.L.; Hamaker, J.M.; Capo, B. Specificity of Host:Pathogen Genetic Interaction for Fusiform Rust Disease on Slash Pine. In Proceeding of the 22nd Southern Forest Tree Improvement Conference, Atlanta, GA, USA, 14-17 June 1993; pp. 403-410.

59. Isik, F.; Amerson, H.V.; Whetton, R.W.; Garcia, S.A.; Li, B.; McKeand, S. Resistance of Pinus. taeda families under artificial inoculations with diverse fusiform rust pathogen populations and comparisons with field trials. Can. J. For. Res. 2008, 38, 2687-2696.

60. Kong, X. RAPD Mapping and Its Application in Slash Pine Breeding. Ph.D. Thesis, Texas A\&M University, College Station, TX, USA, 1996; p. 124.

61. McKeand, S.; Mullin, T.; Byram, T.; White, T. Deployment of genetically improved loblolly and slash pine in the South. J. For. 2003, 101, 32-37.

62. Schmidt, R.A. Fusiform Rust Disease of Southern Pines: Biology, Ecology and Management; Technical Bulletin 903; University of Florida, Agricultural Experiment Station, Institute of Food and Agricultural Sciences: Gainesville, FL, USA, 1998; p. 14.

63. Schmidt, R.A. Fusiform rust of southern pines: A major success for forest disease management. Phytopathology 2003, 93, 1048-1051.

64. Dinus, R.J.; Schmidt, R.A. Management of fusiform rust in southern pines. In Proceedings of a Symposium Sponsored by the Southern Forest Disease and Insect Research Council, University of Florida, Gainesville, FL, USA, 7-8 December 1976.

65. Cubbage, F.W.; Pye, J.M.; Holmes, T.P.; Wagner, J.E. An economic evaluation of fusiform rust research. South. J. Appl. For. 2000, 24, 77-85.

66. Starkey, T.E.; Enebak, S.A. The Use of Proline (Prothioconazole) to Control Pitch Canker, Rhizoctonia Foliage Blight, and Fusiform Rust in Forest Seedling Nurseries and Efforts to Acquire Registration. In National Proceedings: Forest and Conservation Nursery Associations2010. Proc. RMRS-P-65; Riley, L.E., Haase, D.L., Pinto, J.R., Eds.; USDA Forest Service, Rocky Mountain Research Station: Fort Collins, CO, USA, 2011; pp. 49-57.

67. Enebak, S.A. New Fungicide to Treat Pine Seedling Diseases. In Alabama's TREASURED Forests Magazine-Fall 2012; Alabama Forestry Commission: Montgomery, AL, USA, 2012; p. 30. Available online: www.forestry.alabama.gov (accessed on 20 April 2013).

(C) 2013 by the authors; licensee MDPI, Basel, Switzerland. This article is an open access article distributed under the terms and conditions of the Creative Commons Attribution license (http://creativecommons.org/licenses/by/3.0/). 